\title{
Naturally Occurring Uranium in Groundwater in Northeastern Washington State
}

\section{What is uranium?}

Uranium is a radioactive element (radionuclide) that occurs naturally in rock, soil, and water, usually in low concentrations. Radionuclides are unstable atoms with excess energy and as radionuclides decay, they emit radiation. The uranium decay sequence also includes other radionuclides of concern such as radium and radon (DeSimone and others, 2014). This fact sheet addresses naturally occurring uranium in groundwater in northeastern Washington. Radium and radon also occur naturally in the same area, but little is known about their occurrence in area groundwater. A map of Washington State (fig. 1) shows the potential exposure to radon in air based on the presence of uranium-bearing rocks or sediment.

\section{Why is uranium in drinking water a concern?}

Long-term exposure to elevated levels of uranium in drinking water can result in kidney damage and an increased risk of developing cancer. Individual risk depends on many factors including the concentration of uranium in the water, how much water is consumed and for how long, and the age and general health of the individual.

The U.S. Environmental Protection Agency (EPA) establishes water-quality standards for public water-supply systems. Standards are established by considering what levels of a contaminant are protective of human health as well as the feasibility of treatment of water supplies including analytical methods and costs. For uranium, the standard is set at 30 micrograms per liter (U.S. Environmental Protection Agency, 2000). Public water-supply systems are required to meet this standard or treat the water prior to distribution to customers.

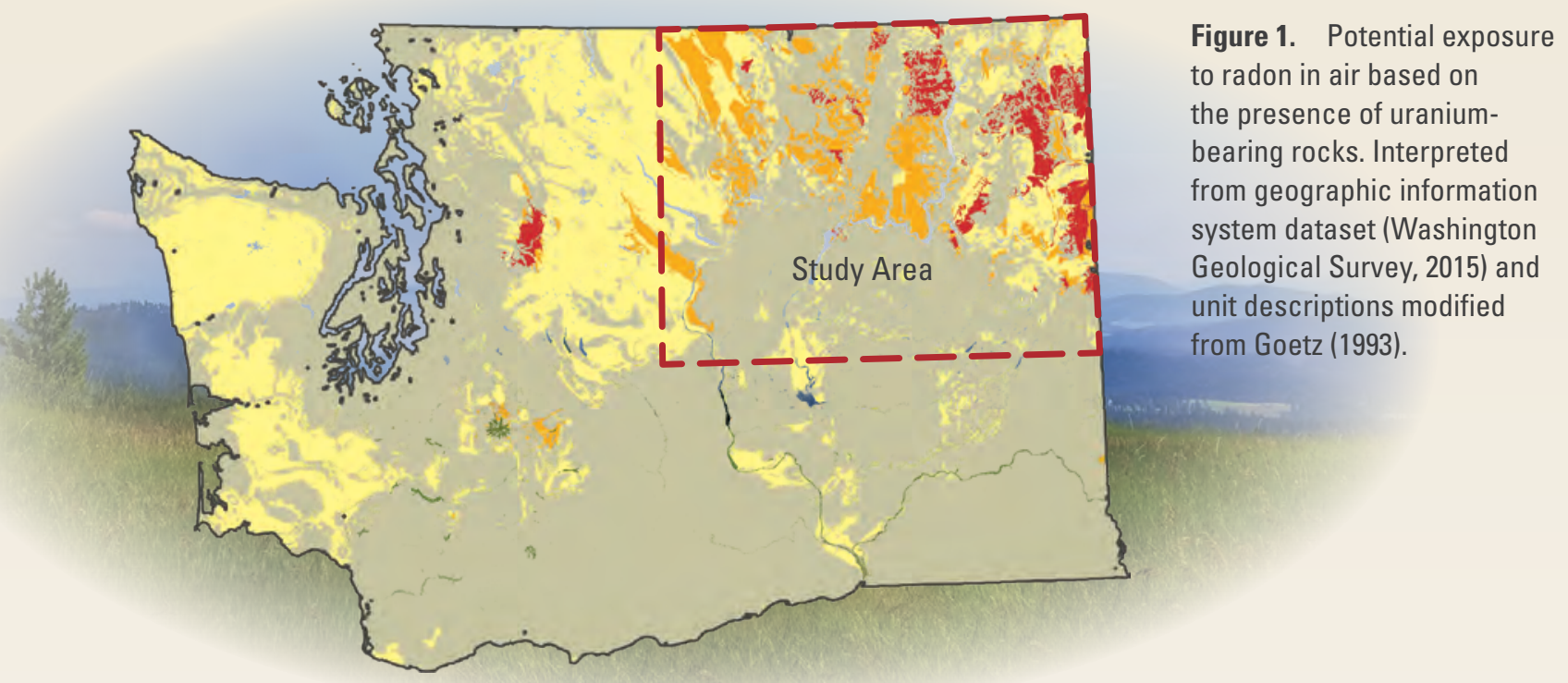

Radon Hazard Classification

\section{EXPLANATION}

High - Geologic units that host uranium mines and prospects and (or) rocks that assayed at greater than 50 parts per million uranium.

Moderately high - Same geologic units as High category but without uranium mines and prospects and (or) rocks that assayed at greater than or equal to 30 and less than or equal to 50 parts per million uranium.

Moderate - Rock types that are known worldwide to contain uranium or rocks in Washington that assayed at greater than or equal to 20 and less than 30 parts per million uranium.

Variable or low - Geologic units that generally have low uranium concentrations and (or) rocks that assayed at less than 20 parts per million uranium or rock units with no data. 

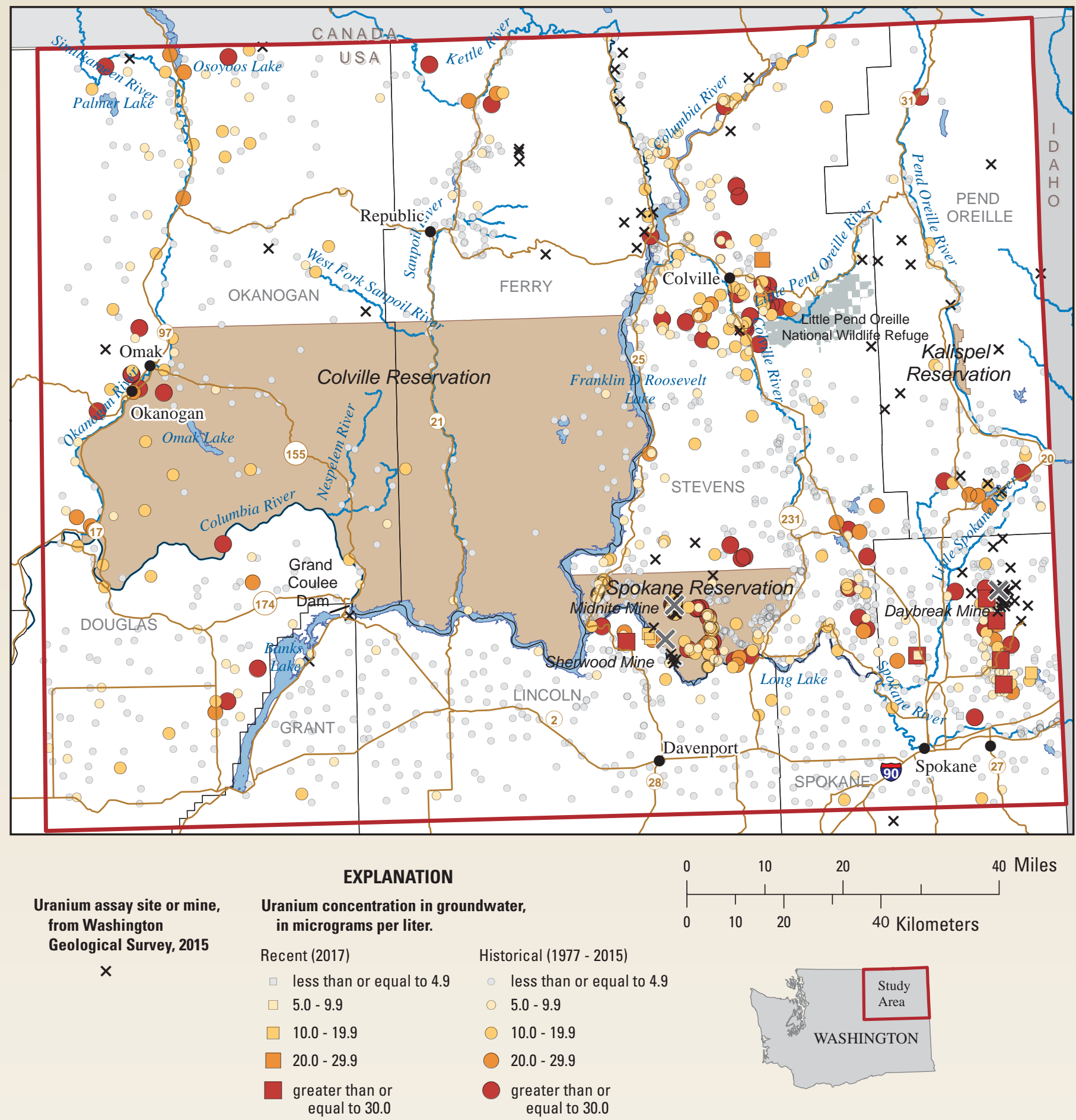

\begin{tabular}{|c|c|}
\hline cent (2017) & Historical (1977 - 2015) \\
\hline less than or equal to 4.9 & less than or equal to 4.9 \\
\hline $5.0-9.9$ & $\quad 5.0-9.9$ \\
\hline $10.0-19.9$ & $10.0-19.9$ \\
\hline $20.0-29.9$ & $20.0-29.9$ \\
\hline $\begin{array}{l}\text { greater than or } \\
\text { equal to } 30.0\end{array}$ & $\begin{array}{r}\text { greater than or } \\
\text { equal to } 30.0\end{array}$ \\
\hline
\end{tabular}

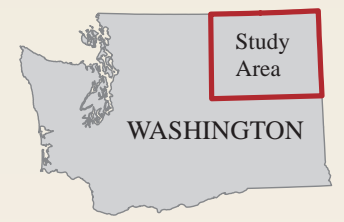

Figure 2. Location of study area and magnitude and distribution of historical (1977-2015) and recent (2017) uranium concentrations in untreated groundwater samples, northeastern Washington. Modified from Kahle and others (2018).

\section{Why is it important to test my drinking water?}

Most rural residents rely on private wells for their source of drinking water. Although public-water supply operators are required to test their water periodically for uranium and other constituents, no monitoring requirements exist for private wells. Therefore, individual well owners are responsible for the quality and safety of their well water. Because radionuclides in water are tasteless, odorless, and colorless, the only way to determine their presence is by testing the water.

Water from most wells in the area has concentrations of uranium well below the drinking water standard, but the amount of uranium in area groundwater varies greatly from place to place (fig. 2). It is possible for closely-spaced wells of similar depths to produce water with very different uranium concentrations. 


\section{Why does uranium occur in groundwater in northeastern Washington?}

Northeastern Washington is a mineral-rich area and has a long history of exploration and mining for various metals, including uranium. Naturally occurring uranium is associated with granitic and metasedimentary rocks, as well as younger sedimentary deposits. Uranium ore was discovered in Washington in the 1950s and was mined at several locations in this area; uranium assays (prospects) also occur throughout the region (fig. 2).

Where uranium minerals are present in rocks, uranium can get into groundwater when groundwater dissolves minerals that contain uranium. Although uranium has been detected in groundwater from all rock types in the area, wells with a higher likelihood of having elevated levels of uranium are those drawing water from areas with granite or shale bedrock (Kahle and others, 2018).

\section{What levels of uranium have been found in area wells?}

To learn more about uranium in groundwater of northeastern Washington, the U.S. Geological Survey made a preliminary assessment of naturally occurring uranium in untreated groundwater, relying on historical data and limited recent sampling (Kahle and others, 2018). Of the 1,742 historically sampled wells (1977-2015), uranium was detected in samples from 60 percent of the wells and samples from 87 wells (5 percent) exceeded the standard for uranium.
In 2017, groundwater samples were collected from 13 private domestic wells in areas without recent (2000s) waterquality data and where granite or shale was predominant-thus,

in areas suspected of having a higher likelihood of elevated uranium levels in the groundwater. Uranium was detected in samples from all 13 wells and samples from 6 of the wells (46 percent) exceeded the standard; uranium concentrations in samples from 2 wells were nearly 40 times the standard.

Locations of the historically and recently sampled wells, plotted by ranges of concentrations of uranium in groundwater samples, are shown in figure 2; those shown in red exceed the standard for uranium. It is important to note that the number of wells sampled represents only about 4 percent of the total number of wells in the study area and much of the study area lacks available uranium concentration data.

\section{What else could we learn?}

Although much has been learned about uranium in the groundwater of northeastern Washington, there are data gaps that, if addressed in the future, could provide area residents with a better understanding of the occurrence and distribution of uranium and other radionuclides in area groundwater. Key data gaps include the following:

- Much of the study area is underrepresented in terms of available uranium concentration data and much of the existing data are decades old.

- The local geochemical conditions that largely govern the mobility of uranium are poorly understood and would be helpful in understanding its occurrence in area groundwater.

- The uranium decay sequence includes other radionuclides of concern (radium, radon, and alpha particles) but very little is known about their presence in area groundwater.

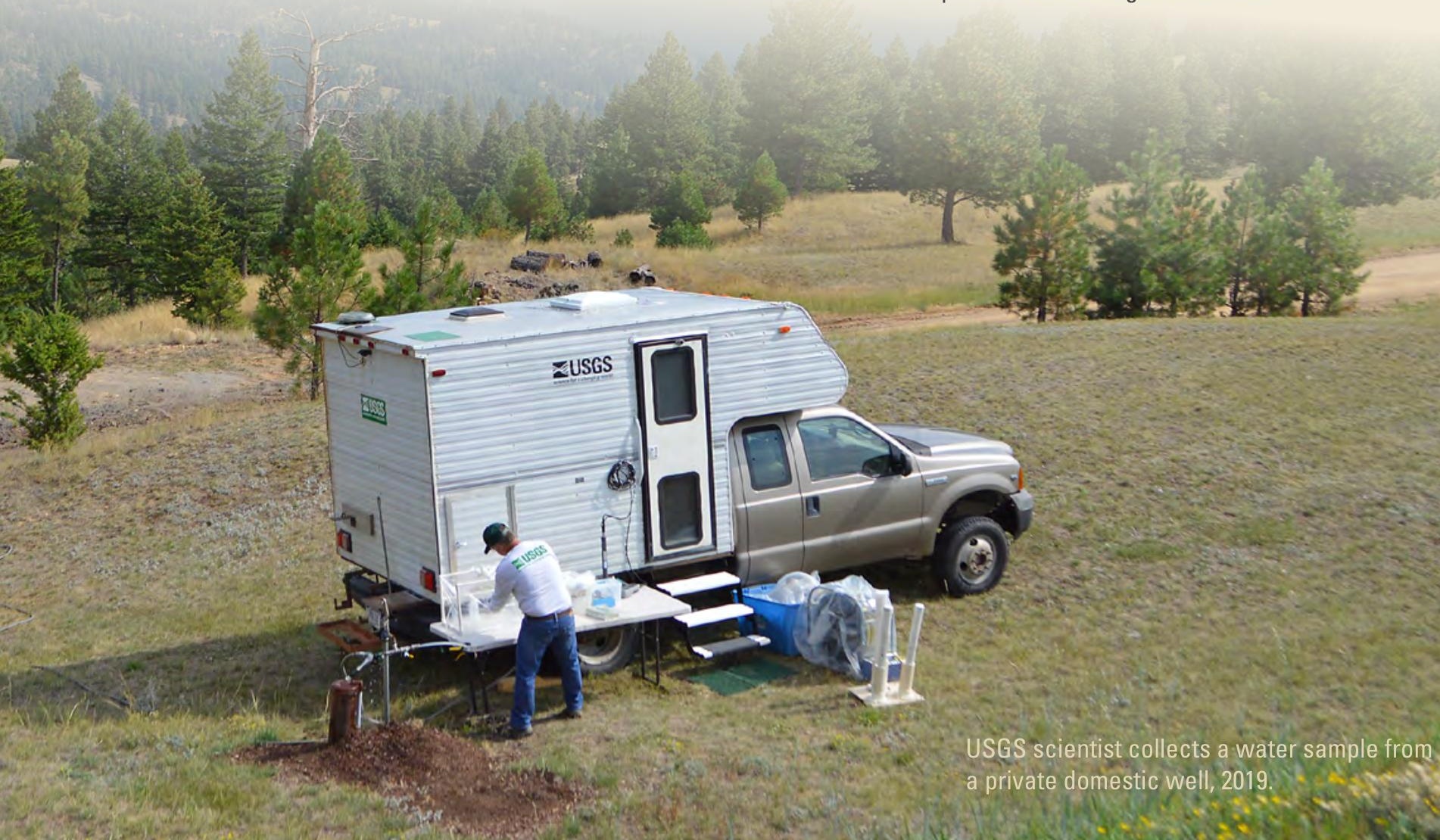




\section{Where can I find more information?}

- Local health departments often can provide information about water testing and treatment options available in the areas that they serve.

- The Washington Department of Ecology maintains a list of accredited laboratories that accept well water for testing. See their "Testing drinking water" web page at https://ecology. wa.gov/Water-Shorelines/Watersupply/Wells/Testing-drinking-water.

- A Washington State Department of Health fact sheet describing Radionuclides in Drinking Water is available at www.doh.wa.gov/ portals/1/Documents/pubs/331-056.pdf.

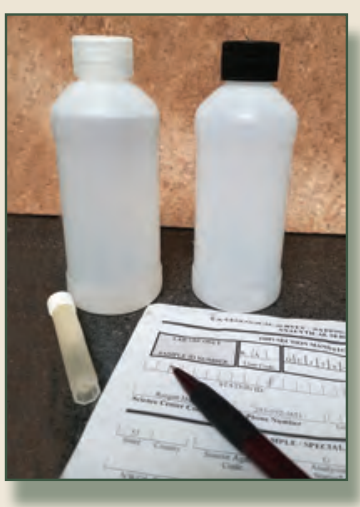

- A U.S. Environmental Protection Agency web page about Natural Radionuclides in Private Wells is available at https://www.epa.gov/radtown/natural-radionuclides-private-wells.

- A U.S. Environmental Protection Agency web page about uranium is available at https://www.epa.gov/radiation/radionuclide-basics-uranium.

- A Washington State Department of Health web page and interactive map about radon risk in air are available at https://www.doh.wa.gov/YouandYourFamily/HealthyHome/ Contaminants/Radon.

- The U.S. Geological Survey maintains a web site dedicated to ongoing scientific studies of radionuclides in water at https://www.usgs.gov/mission-areas/water-resources/science/ radionuclides?qt-science_center_objects=0\#qt-science_ center_objects.

\section{References}

DeSimone, L.A., McMahon, P.B., and Rosen, M.R., 2014, The quality of our Nation's waters-Water quality in principal aquifers of the United States, 1991-2010: U.S. Geological Survey Circular 1360, 151 p., http://dx.doi.org/10.3133/ cir1360.

Goetz, V.L., 1993, Radon potential of Washington from a geologic viewpoint, in Washington Geology: Washington Department of Natural Resources, Division of Geology and Earth Resources, v. 21, No. 2, July 1993, p. 11-14.

Kahle, S.C., Welch, W.B., Tecca, A.E., and Eliason, D.M., 2018, Uranium concentrations in groundwater, northeastern Washington: U.S. Geological Survey Scientific Investigations Map 3401, 1 sheet, https://doi.org/10.3133/sim3401.

U.S. Environmental Protection Agency, 2000, Technical fact sheet-Final rule for (non-radon) radionuclides in drinking water, EPA 815-F-00-013, https://www.epa.gov/dwreginfo/radionuclides-rule.

Washington Geological Survey, 2015, Hazardous minerals database - GIS data: Washington Division of Geology and Earth Resources Digital Data Series 15, version 1.0., accessed May 2017, at http://www.dnr.wa.gov/publications/ger_portal_ hazardous_minerals.zip.

\section{Photograph credits:}

Banner and inside lower right, Vickie Caldwell. Sunflowers, Sue Kahle. Drinking water, Elizabeth Benson. Sample bottles, LisI Fasser.

Authors:

Sue C. Kahle

For more information:

Director, Washington Water Science Center U.S. Geological Survey

934 Broadway, Suite 300, Tacoma, Washington 98402 https:/www.usgs.gov/centers/wa-water

\section{Project web page at:}

https://www,usgs gov/centers/wa-water/science/uraniumgroundwater?qt-science_center_objects $=0 \#$ qt-science center_objects

Publishing support provided by the U.S. Geological Survey Science Publishing Network, Tacoma Publishing Service Center 